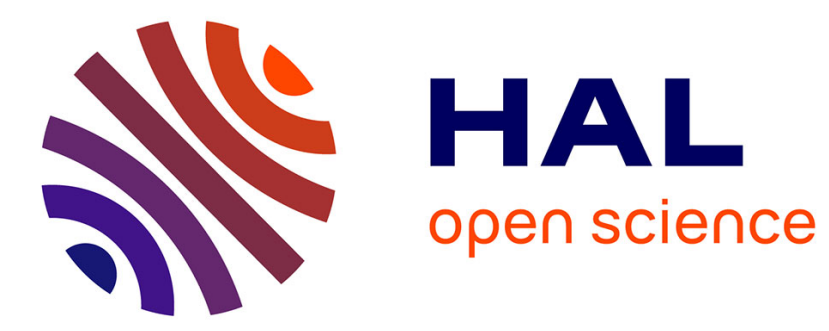

\title{
New growth media for oral bacteria
}

Bénédicte Martin, Kanchana Chathoth, Souad Ouali, Vincent Meuric, Martine Bonnaure-Mallet, Christine Baysse

\section{To cite this version:}

Bénédicte Martin, Kanchana Chathoth, Souad Ouali, Vincent Meuric, Martine Bonnaure-Mallet, et al. New growth media for oral bacteria. Journal of Microbiological Methods, 2018, 153, pp.10-13. 10.1016/j.mimet.2018.08.013 . hal-01880154

\section{HAL Id: hal-01880154 https://hal-univ-rennes1.archives-ouvertes.fr/hal-01880154}

Submitted on 17 Jan 2019

HAL is a multi-disciplinary open access archive for the deposit and dissemination of scientific research documents, whether they are published or not. The documents may come from teaching and research institutions in France or abroad, or from public or private research centers.
L'archive ouverte pluridisciplinaire HAL, est destinée au dépôt et à la diffusion de documents scientifiques de niveau recherche, publiés ou non, émanant des établissements d'enseignement et de recherche français ou étrangers, des laboratoires publics ou privés. 
New growth media for oral bacteria

Bénédicte Martin, Kanchana Chathoth, Souad Ouali, Vincent Meuric, Martine Bonnaure-Mallet, Christine Baysse

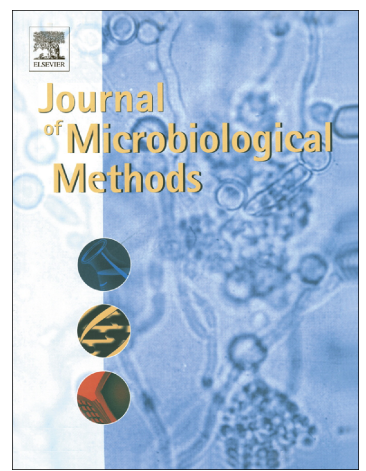

PII: $\quad$ S0167-7012(18)30595-5

DOI: $\quad$ doi:10.1016/j.mimet.2018.08.013

Reference: $\quad$ MIMET 5459

To appear in: Journal of Microbiological Methods

Received date: $\quad 19$ July 2018

Revised date: 27 August 2018

Accepted date: 27 August 2018

Please cite this article as: Bénédicte Martin, Kanchana Chathoth, Souad Ouali, Vincent Meuric, Martine Bonnaure-Mallet, Christine Baysse, New growth media for oral bacteria. Mimet (2018), doi:10.1016/j.mimet.2018.08.013 


\section{New growth media for oral bacteria}

Bénédicte Martin ${ }^{1}$, Kanchana Chathoth ${ }^{1}$, Souad Ouali ${ }^{2}$, Vincent Meuric ${ }^{1}$, Martine Bonnaure-Mallet ${ }^{1}$ and Christine Baysse ${ }^{1 *}$

${ }^{1}$ CIMIAD, U1241 NUMECAN, Université de Rennes 1, 2 av. du Pr. Léon Bernard 35043 Rennes, France

2 EA1254 Microbiologie-Risques Infectieux, Université de Rennes 1, 2 av. du Pr. Léon Bernard 35043 Rennes, France

* Corresponding author: christine.baysse@univ-rennes1.fr

\section{Abstract}

New growth media have been designed for the iron-controlled co-cultures of three oral bacteria. These media share a common core composition enabling the switch from mono- to co-cultures, and efficiently promote both planktonic and biofilm cultures of Porphyromonas gingivalis, Treponema denticola and Streptococcus gordonii.

Keywords: Porphyromonas gingivalis, Treponema denticola, Streptococcus gordonii, Periodontitis, Iron, Growth media

Periodontitis is characterized by the damage of periodontal tissues causing periodontal pockets and bone loss, leading to tooth loss. The evolution of the disease is linked to a modification of the oral microbiota (Meuric et al., 2017a). Anaerobic bacteria are closely associated with the transition from healthy to pathological conditions. The virulent switch of the microbiota may be influenced by host-related factors such as systemic iron levels. Indeed, a recent study demonstrated that severe periodontitis was associated with the severity of iron burden in patients with HFErelated hereditary haemochromatosis, an autosomal recessive genetic disease leading to iron overload (Meuric et al., 2017b). To further evaluate the impact of iron concentration on the fitness of the oral microbiota, we developed a simplified experimental model with bacterial species for which interactions are known to influence the evolution of periodontal disease, namely Streptococcus gordonii (primary colonizer), Porphyromonas gingivalis and Treponema denticola (anaerobic 
pathogens)(Ng et al., 2016). P. gingivalis and T. denticola are keystone pathogens strongly associated with the severity of the disease (Orth et al., 2011). They were frequently found together in deep periodontal pockets (Byrne et al., 2009; Tan et al., 2014). Both species are anaerobic fastidious organisms and all experiments so far were carried out in complex media such as OMZ-M (Wyss, 2007), OBGM (Orth et al., 2010) and BM (Loo et al., 2000). However, to further study the role of iron, it is important to avoid empirical components such as brain heart infusion and yeast extract, which are usually contaminated with high residual concentrations of iron. In this study, new growth media, with only bovine serum albumin (BSA), casamino acids (CAA) and/or glucose as carbon sources, were designed for the individual- or cocultures of $P$. gingivalis, T. denticola and S. gordonii (Medium for Mixed Bacterial Community, MMBC) (Table 1).

Table 1. Composition of MMBC media

\begin{tabular}{|c|c|c|c|c|}
\hline & $\begin{array}{c}\text { Medium Type } \\
\text { on concentration in } \mu\end{array}$ & & Co & iposition \\
\hline & & MMBC-1 & $\mathrm{NaH}_{2} \mathrm{PO}_{4}$ & $5 \mathrm{mM}$ \\
\hline & & $\log 15+100500)$ & $\mathrm{KCl}$ & $5 \mathrm{mM}$ \\
\hline & & $(0.45+1-1.395-02)^{6}$ & $\mathrm{MgCl}_{2} \cdot 7 \mathrm{H}_{2} \mathrm{O}$ & $5 \mathrm{mM}$ \\
\hline & & & Menadione & $0.581 \mu \mathrm{M}$ \\
\hline & & & BSA & $3675 \mathrm{mg} \mathrm{L}^{-1}$ \\
\hline & & & CAA & $2500 \mathrm{mg} \mathrm{L}^{-1}$ \\
\hline & & & Adenine & $1.35 \mathrm{mg} \mathrm{L}^{-1}$ \\
\hline & MMBC-2 & & FAD & $1 \mathrm{mg} \mathrm{L}^{-1}$ \\
\hline & 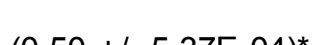 & & Folic acid & $1 \mathrm{mg} \mathrm{L}^{-1}$ \\
\hline & $(0.50+1-3.3 / 5-04)$ & & Pyridoxal phosphate & $5 \mathrm{mg} \mathrm{L}^{-1}$ \\
\hline & & & Fumarate & $0.5 \mathrm{~g} \mathrm{~L}^{-1}$ \\
\hline & & & Pyruvate & $0.55 \mathrm{~g} \mathrm{~L}^{-1}$ \\
\hline & & & TPP & $25 \mathrm{mg} \mathrm{L}^{-1}$ \\
\hline & & & Inosine & $2.7 \mathrm{mg} \mathrm{L}^{-1}$ \\
\hline & & & CoA & $1 \mathrm{mg} \mathrm{L}^{-1}$ \\
\hline & & & Volatile fatty acids** & $0.001 \%(\mathrm{v} / \mathrm{v})$ each \\
\hline & & & D-Biotin & $0.05 \mu \mathrm{M}$ \\
\hline & & & Nicotinic acid & $0.04 \mathrm{mM}$ \\
\hline & & & D-Glucose & $6 \mathrm{~g} \mathrm{~L}^{-1}$ \\
\hline MIMBC-3 & & & $\mathrm{MnSO}_{4}$ & $10 \mathrm{mg} \mathrm{L}^{-1}$ \\
\hline$(0.56+/-4.30 \mathrm{E}-03)^{*}$ & & & L-Arginine-HCI & $1 \mathrm{mM}$ \\
\hline & & & L-Tryptophan & $0.1 \mathrm{mM}$ \\
\hline & & & Cysteine- $\mathrm{HCl}$ & $1.3 \mathrm{mM}$ \\
\hline & & & L-Glutamic acid & $4 \mathrm{mM}$ \\
\hline
\end{tabular}




\begin{tabular}{|l|l|l|l|l|}
\hline & & & $\left(\mathrm{NH}_{4}\right)_{2} \mathrm{SO}_{4}$ & $0.6 \mathrm{~g} \mathrm{~L}^{-1}$ \\
\hline
\end{tabular}

*Data are the average concentrations of two independent freshly prepared media ${ }^{* *}$ Volatile fatty acids: valeric acid, isovaleric acid and isobutyric acid.

Table 1

A core composition sufficient for the growth of $P$. gingivalis (MMBC-1) was further supplemented with components necessary for the growth of $T$. denticola (MMBC-2) and $S$. gordonii (MMBC-3). The quantification of iron in the MMBC media was performed by Inductively Coupled Plasma Mass Spectrometry (ICP-MS), on X-Series II from Thermo Scientific $®$ equipped with collision cell technology (AEM2 Facility, University of Rennes 1), as previously described (Cavey et al., 2015). All three media contained less than $0.56 \mu \mathrm{M}$ of iron (Table 1), making them suitable for iron metabolism/transport related studies. These media were first tested for planktonic mono- or cocultures in anaerobic conditions at $37^{\circ} \mathrm{C}$.

A

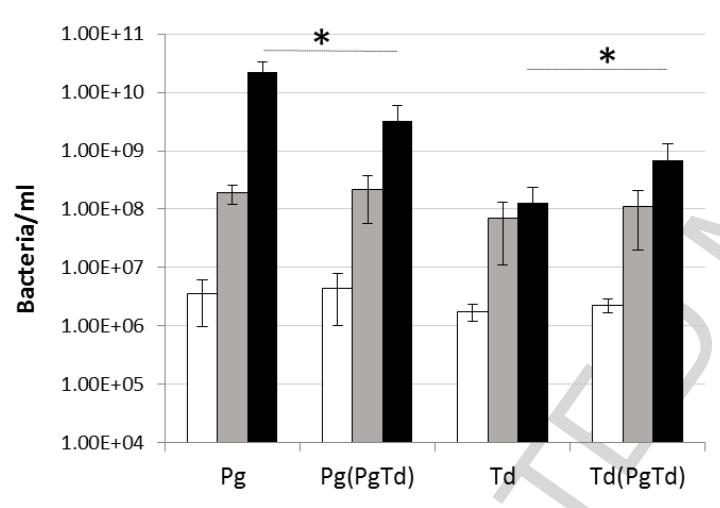

C

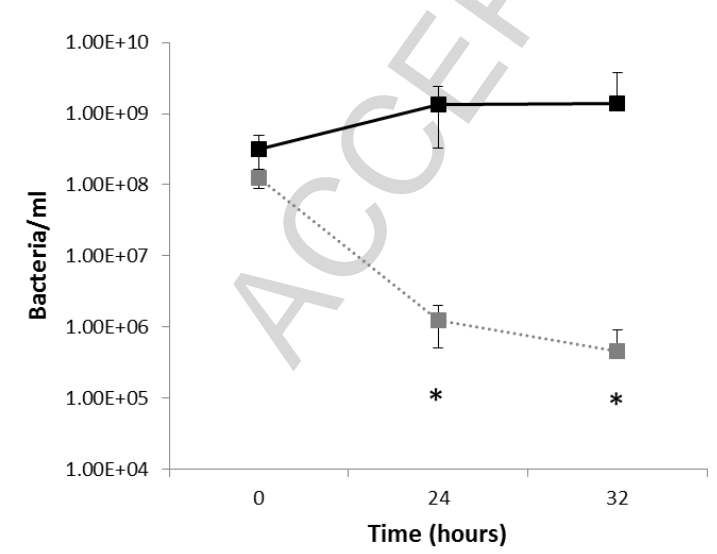

B

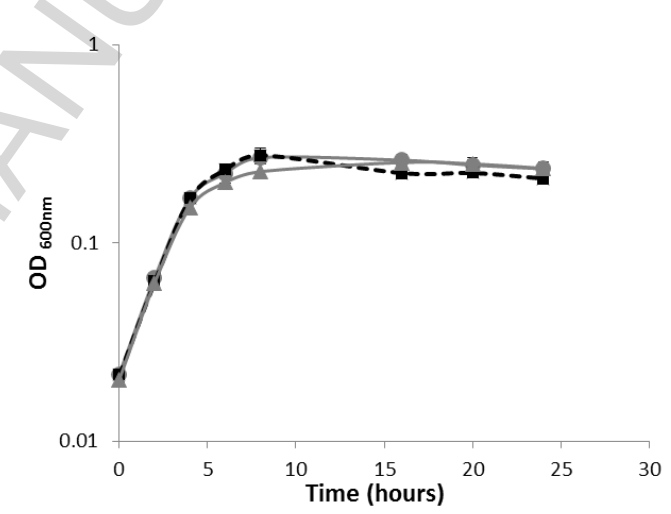

D

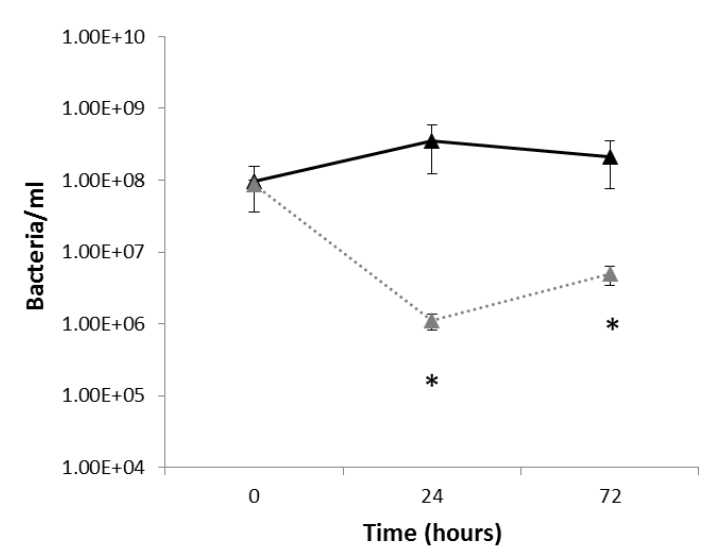

Figure 1. Planktonic cultures 
A) Mono- and cocultures of $P$. gingivalis and $T$. denticola were grown in MMBC-3 media with $8 \mu \mathrm{M}$ of hemin. Quantification of bacterial species in cocultures was carried out by GPCR. Samples were collected at 0 (white bars), 30 (grey bars) and 100 hours (black bars) after anaerobic incubation at $37^{\circ} \mathrm{C}$. Pg: monocultures of $P$. gingivalis. $\mathrm{Pg}(\mathrm{PgTd})$ : quantification of $P$. gingivalis when cocultured with T. denticola. Td: monocultures of $T$. denticola. $\mathrm{Td}(\mathrm{PgTd})$ : quantification of $T$. denticola when cocultured with $P$. gingivalis. Data are the average of triplicate assays. $p$ values were calculated with student's $T$ test. $\left.{ }^{*} \mathrm{p}<0.05,{ }^{* *} \mathrm{p}<0.01 . \mathrm{B}\right) \mathrm{S}$. gordonii Challis $\mathrm{DL} 1$ was grown in MMBC-3 plus $8 \mu \mathrm{M}$ hemin (grey

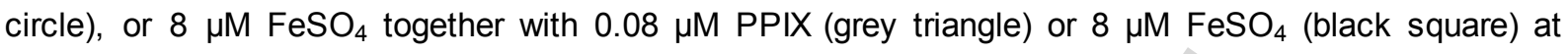
$37^{\circ} \mathrm{C}$ in anaerobic conditions. OD values are the average of 3 experiments. C) Growth and survival of $P$. gingivalis and D) T. denticola were monitored at $37^{\circ} \mathrm{C}$, in anaerobic condition, in MMBC-3 with $8 \mu \mathrm{M}$ hemin, in the presence (grey symbol) or absence (black symbol) of S. gordonii. Quantifications of $T$. denticola and $P$. gingivalis in cocultures were carried out by qPCR. Data are the average of 3 experiments performed in triplicates. $p$ values were calculated with student's T-test; ${ }^{*} p<0.05,{ }^{* *} p<0.01$. Figure 1

Strains of S. gordonii Challis DL1 (Chen et al., 2004), P. gingivalis TDC60 (Watanabe et al., 2011) and T. denticola ATCC35405 (Chan et al., 1993) were used. For monocultures, the growth of each species was measured by optical density at 600 $\mathrm{nm}$ over a period of time in MMBC media supplemented with hemin or $\mathrm{FeSO}_{4}$ as iron sources. For cocultures, quantification of each bacterial species at different time points was carried out by qPCR with species-specific 16S rRNA primers as previously described (Ammann et al., 2013; Martin et al., 2017)(Fig. 1). Monocultures of $P$. gingivalis grew similarly in all MMBC media containing hemin or ferrous iron with protoporphyrin IX (PPIX) (Fig. 1A for MMBC-3). $8 \mu \mathrm{M}$ of hemin was found as the optimal concentration for $P$. gingivalis growth (data not shown). The removal of hemin impaired the growth of $P$. gingivalis and T. denticola (data not shown). Without hemin, the growth of $T$. denticola was restored by $8 \mu \mathrm{M}$ of $\mathrm{FeSO}_{4}$, whereas $P$. gingivalis needed both $\mathrm{FeSO}_{4}$ and protoporphyrin IX (PPIX) (data not shown). The optimal concentration of PPIX that promoted the growth of $P$. gingivalis without impairing the growth of $T$. denticola was defined as $0.08 \mu \mathrm{M}$. Moreover, addition of PPIX in $\mathrm{FeSO}_{4}$ containing MMBC-3 was not required for the growth of $S$. gordonii (Fig.1B). The growth of $T$. denticola was enhanced by co-culture with $P$. gingivalis in MMBC-2 (data not shown) and in MMBC-3 (Fig.1A) such as it was previously observed in the rich OBGM medium which contained yeast extract and brain heart infusion as carbon sources (Tan et al., 2014). Interestingly, an antagonistic behaviour was observed in 
co-cultures of $S$. gordonii with either P. gingivalis (Fig. 1C) or T. denticola (Fig. 1D). The presence of $S$. gordonii impeded the growth and survival of both pathogens.

To assess bacterial growth in sessile conditions, biofilms were grown in sterile $\mu$-slide 8-chambered coverslip (ibiTreat, Ibidi), that were previously coated with $0.22-\mu \mathrm{m}$ filtered sterile human saliva $(25 \% \mathrm{v} / \mathrm{v})$ collected from at least six healthy volunteers (Martin et al., 2017). Formation of three-species biofilms in anaerobic conditions at $37^{\circ} \mathrm{C}$ was evaluated in MMBC-3 medium plus hemin or $\mathrm{FeSO}_{4}$ and $\mathrm{PPIX}$, as compared with brain-heart infusion broth (BHle) (Biomérieux, France) supplemented with menadione $\left(10 \mu \mathrm{g} \mathrm{mL}{ }^{-1}\right)$ and hemin $\left(5 \mu \mathrm{g} \mathrm{mL}{ }^{-1}\right)$. At 24 hours, biofilms were stained with $5 \mu \mathrm{M}$ of Sytoß40 nucleic acid dye, a blue fluorescent membranepermeant stain (Molecular Probes, Lieden, The Netherlands) and $40 \mu \mathrm{M}$ of Propidium lodide (Thermo Fisher) diluted in PBS before observation in situ with a Leica TCSSP8 confocal laser scanning microscope (Leica Microsystems, Wezlar, Germany). After imaging, bacteria collected from biofilms were quantified by qPCR as described by Martin et al., (2017). 
A

Medium

MMBC-3

Hemin

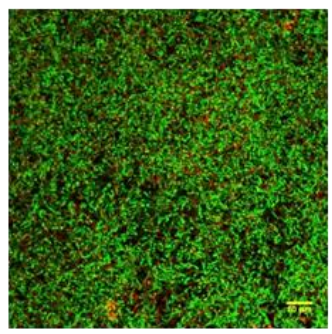

MMBC-3

$\mathrm{PPIX} / \mathrm{FeSO}_{4}$

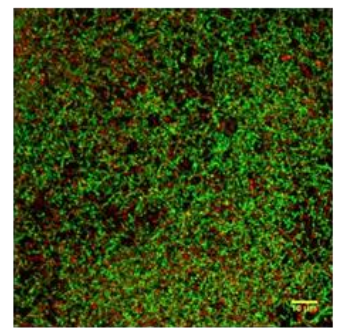

BHle

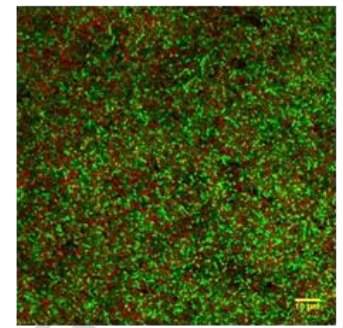

\begin{tabular}{l|l|l|l}
\hline Total biomass $\left(\mu \mathrm{m}^{3} / \mu \mathrm{m}^{2}\right)$ & 13.42 & 9.25 & 7.95 \\
\hline
\end{tabular}

B

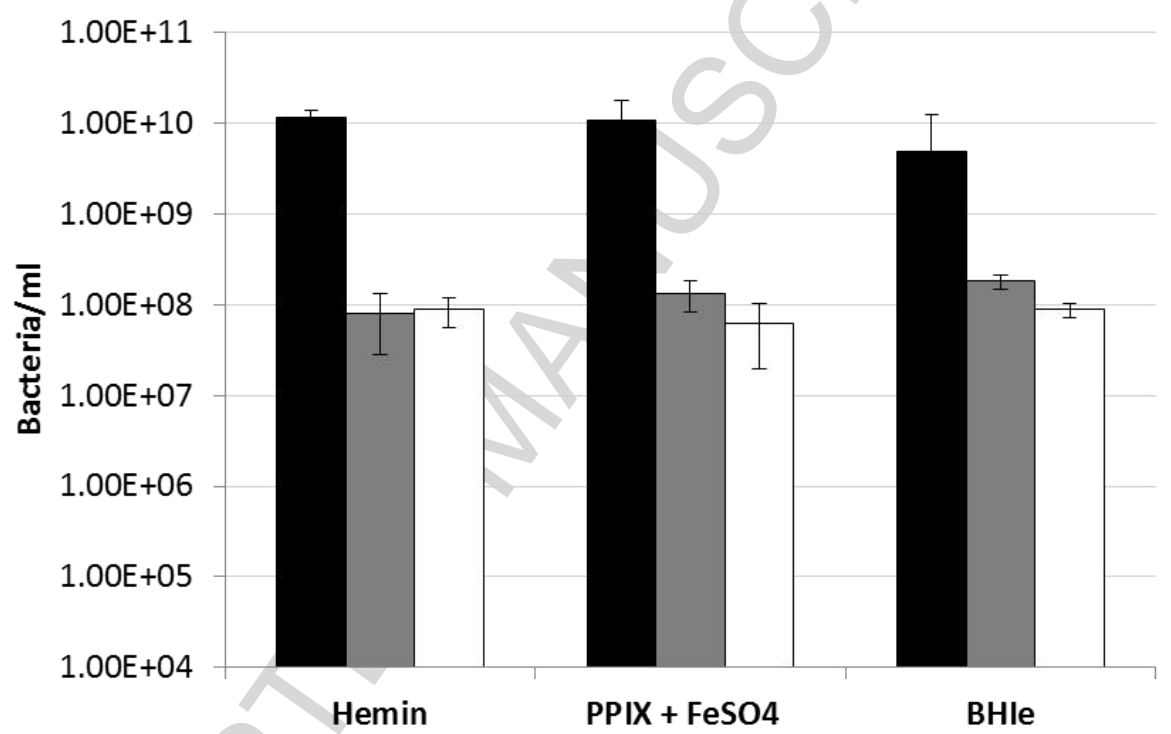

Figure 2. Three-species biofilms in MMBC-3 with different iron sources as compared with BHle Biofilms were grown in MMBC-3 medium plus $8 \mu \mathrm{M}$ hemin or $8 \mu \mathrm{M} \mathrm{FeSO}{ }_{4} / 0.08 \mu \mathrm{M}$ PPIX or in BHle. 24-hours biofilms stained with Syto®40 nucleic acid dye (Live cells-green colour) and Propidium lodide (Dead cells-red colour). A). The figure shows representative images of 3 experiments with the 3D maximum $z$ projection. The biomass $\left(\mu^{3} / \mu \mathrm{m}^{2}\right)$ was estimated using Comstat 2 plugin of ImageJ software V1.43m (National Institute of Health). B) After 24 hours of incubation in anaerobic conditions at $37^{\circ} \mathrm{C}$, the concentration of bacteria was quantified by qPCR: $S$. gordonii, black bars; $P$. gingivalis, grey bars; $T$. denticola, white bars. The data are the average of triplicate assays.

Figure 2

As demonstrated by image analysis and qPCR measurements, biofilms performed in MMBC-3 media displayed similar biomasses as biofilms in BHle (Fig 2A), with identical ratios of each species (Fig. 2B). As expected from previous observations of 
2-species biofilms (Martin et al., 2017), the proportion of S. gordonii in three-species biofilms was always higher than those of $P$. gingivalis and $T$. denticola, probably due to its higher growth rate and antagonistic behaviour.

\section{Conclusion}

From the simplest medium composition for $P$. gingivalis (MMBC-1), supplemented media were designed and validated for the growth of $P$. gingivalis together with $T$. denticola (MMBC-2) and the growth of the two anaerobic pathogens together with $S$. gordonii (MMBC-3), allowing an increment in the complexity of the media as per need. These media are suitable for biofilm mode of growth and are specifically designed to control the levels of iron and the nature of iron sources, unlike rich media which are generally used for growing a mixed biofilm, comprising of these fastidious oral bacteria.

This work was supported by the Conseil Régional de Bretagne, France (F3/48 CPER), the Fondation "Les Gueules Cassées/Sourire Quand Même" and the Federative Research Structure Biosit (Rennes). We thank M. Ropert for ICP-MS analysis. We also thank all people of the Microscopy Rennes Imaging Center (Biosit) for technical assistance for microscopy experiments.

Declarations of interest: none

\section{References}

Ammann, T.W., Bostanci, N., Belibasakis, G.N., and Thurnheer, T. (2013). Validation of a quantitative real-time PCR assay and comparison with fluorescence microscopy and selective agar plate counting for species-specific quantification of an in vitro subgingival biofilm model. J. Periodontal Res. 48, 517-526.

Byrne, S.J., Dashper, S.G., Darby, I.B., Adams, G.G., Hoffmann, B., and Reynolds, E.C. (2009). Progression of chronic periodontitis can be predicted by the levels of Porphyromonas gingivalis and Treponema denticola in subgingival plaque. Oral Microbiol. Immunol. 24, 469-477. 
Cavey, T., Ropert, M., de Tayrac, M., Bardou-Jacquet, E., Island, M.-L., Leroyer, P., Bendavid, C., Brissot, P., and Loréal, O. (2015). Mouse genetic background impacts both on iron and non-iron metals parameters and on their relationships. Biometals Int. J. Role Met. lons Biol. Biochem. Med. 28, 733-743.

Chan, E.C.S., Siboo, R., Keng, T., Psarra, N., Hurley, R., Cheng, S.-L., and lugovaz, I. (1993). Treponema denticola (ex Brumpt 1925) sp. nov., nom. rev., and identification of new spirochete isolates from periodontal pockets. Int. J. Syst. Evol. Microbiol. 43, 196-203.

Chen, C.C., Teng, L.J., and Chang, T.C. (2004). Identification of clinically relevant viridans group streptococci by sequence analysis of the 16S-23S ribosomal DNA spacer region. J. Clin. Microbiol. 42, 2651-2657.

Loo, C.Y., Corliss, D.A., and Ganeshkumar, N. (2000). Streptococcus gordonii biofilm formation: identification of genes that code for biofilm phenotypes. J. Bacteriol. 182, 1374-1382.

Martin, B., Tamanai-Shacoori, Z., Bronsard, J., Ginguené, F., Meuric, V., Mahé, F., and Bonnaure-Mallet, M. (2017). A new mathematical model of bacterial interactions in two-species oral biofilms. Plos One 12, e0173153.

Meuric, V., Le Gall-David, S., Boyer, E., Acuña-Amador, L., Martin, B., Fong, S.B., Barloy-Hubler, F., and Bonnaure-Mallet, M. (2017a). Signature of microbial dysbiosis in periodontitis. Appl. Environ. Microbiol. 83:e00462-17.

Meuric, V., Lainé, F., Boyer, E., Le Gall-David, S., Oger, E., Bourgeois, D., Bouchard, P., Bardou-Jacquet, E., Turmel, V., Bonnaure-Mallet, M., et al. (2017b). Periodontal status and serum biomarker levels in HFE haemochromatosis patients. A case-series study. J. Clin. Periodontol. 44, 892-897.

Ng, H.M., Kin, L.X., Dashper, S.G., Slakeski, N., Butler, C.A., and Reynolds, E.C. (2016). Bacterial interactions in pathogenic subgingival plaque. Microb. Pathog. 94, 60-69. 
Orth, R., O'Brien-Simpson, N., Dashper, S., Walsh, K., and Reynolds, E. (2010). An efficient method for enumerating oral spirochetes using flow cytometry. J. Microbiol. Methods 80, 123-128.

Orth, R.K.-H., O'Brien-Simpson, N.M., Dashper, S.G., and Reynolds, E.C. (2011). Synergistic virulence of Porphyromonas gingivalis and Treponema denticola in a murine periodontitis model. Mol. Oral Microbiol. 26, 229-240.

Tan, K.H., Seers, C.A., Dashper, S.G., Mitchell, H.L., Pyke, J.S., Meuric, V., Slakeski, N., Cleal, S.M., Chambers, J.L., McConville, M.J., et al. (2014). Porphyromonas gingivalis and Treponema denticola exhibit metabolic symbioses. PLOS Pathog. 10, e1003955.

Watanabe, T., Maruyama, F., Nozawa, T., Aoki, A., Okano, S., Shibata, Y., Oshima, K., Kurokawa, K., Hattori, M., Nakagawa, I., et al. (2011). Complete genome sequence of the bacterium Porphyromonas gingivalis TDC60, which causes periodontal disease. J. Bacteriol. 193, 4259-4260.

Wyss, C. (2007). Fatty acids synthesized by oral treponemes in chemically defined media. FEMS Microbiol. Lett. 269, 70-76. 